\title{
Urban climate studies in a subtropical location: literature review and current perspectives for Curitiba, Brazil
}

This article was published in the following Dove Press journal:

Energy and Emission Control Technologies

21 October 2015

Number of times this article has been viewed

\author{
Eduardo Krüger' \\ Cintia Tamura ${ }^{2}$ \\ 'Departamento de Construção Civil, \\ 2Programa de Pós-graduação em \\ Tecnologia, Universidade Tecnológica \\ Federal do Paraná - UTFPR, Curitiba, \\ PR, Brazil
}

\begin{abstract}
This review presents a summary of research in urban climate over the past decade and since the first reported studies in the field for Curitiba, Brazil. This city is located just south of the Tropic of Capricorn and has a long tradition in Brazilian urban planning. Due to increasing urban expansion in recent decades, quality of life within the urban area has been decaying (for example, in terms of the thermodynamic subsystem, which includes the development of urban heat islands). The integration of research outcomes and the development of the urban climate field in a more cohesive way could allow researchers to provide guidance for climate-responsive urban design, with consequential life-quality improvements in this location.
\end{abstract}

Keywords: intra-urban air temperature variations, outdoor thermal comfort, urban heat island

\section{Introduction}

Curitiba $\left(25.5^{\circ} \mathrm{S}, 49^{\circ} \mathrm{W}, 910 \mathrm{~m}\right.$ above mean sea level) (PR, Brazil) is located in a tropical climate zone in a relatively high-altitude region of Brazil, and is classified as an oceanic climatic type according to the Köppen-Geiger climate classification. For Brazilian standards, its climate is quite peculiar, and as the capital of the state of Paraná, it is the coldest capital city in Brazil, with frequent night-frost episodes in winter and more clearly defined seasons than in most parts of the country. Other relevant features of this location include its long history of urban planning and an increasing urban expansion in recent decades, which brought several consequences for the quality of life within the urban area.

Urban growth in Brazil (past and present trends) has been suggested to be directly responsible for a decrease in life quality in cities, which within a few decades have seen their population increase three- or fourfold, and Curitiba is no exception. With its rapid process of urbanization starting in the $1950 \mathrm{~s}$, Curitiba has seen its population triple over the last 4 decades (1970-2010). Such urbanization was mostly caused by migratory movements. As the economy of Paraná state was traditionally based on agriculture, with the mechanization of agricultural processes and with the expansion of the industrial sector in the city alongside the creation of the sector called "Cidade Industrial de Curitiba", migration took place towards the state's capital. In the 1990s, as a result of successful urban planning projects along with equally successful city marketing campaigns, many newcomers came seeking a higher quality of life, many of them leaving behind Brazilian megacities such as Rio de Janeiro and São Paulo, which had also experienced the negative consequences of unplanned urbanization. ${ }^{1}$ In some parts of the city, the spatial configuration is characterized by urban canyons along
Correspondence: Eduardo Krüger Universidade Tecnológica Federal do Paraná - UTFPR, Campus Curitiba - Sede Ecoville, Rua Deputado Heitor Alencar Furtado, 4900, 81280-340 Curitiba, PR, Brazil

Tel +554133104725

$\mathrm{Fax}+554133104712$

Email ekruger@utfpr.edu.br 
the so-called "Structural Sectors", which have a pronounced impact on the urban landscape: along those axes, dwellers are faced with challenges including thermal discomfort, lack of daylight, and changes in ventilation patterns leading to possible effects on air quality. ${ }^{2-6}$

This review has the purpose of summarizing the climaterelated research that has been done in Curitiba over the last 2 decades, thereby offering future perspectives for actions and continuing investigations in the fields of climate-responsive urban design, urban climate, and outdoor thermal comfort. Although local climatic conditions are not representative of the larger Brazilian territory - less than 1\% of the country is classified as belonging to the same bioclimatic zone as Curitiba - lessons learned from Curitiba can be applicable to similar latitude and altitude ranges, thus affecting a number of cities in developing countries with similar climatic challenges. $^{7}$

\section{Method}

A search of the research output, in terms of master's and doctoral theses as well as scientific papers, was performed in freely available databases (Scopus, Google Scholar, Banco de Teses CAPES [http://bancodeteses.capes.gov.br/], Biblioteca Digital de Teses e Dissertações - SiBi/UFPR [http://www. portal.ufpr.br/teses acervo.html], and Repositório Digital da UTFPR [http://repositorio.utfpr.edu.br/jspui/]). A search in the main directory of research groups in Brazil (http://lattes. cnpq.br/web/dgp) was additionally carried out for identifying registered research groups in the field of urban climate presently active in Curitiba.

In the survey, the basic search term used was "Clima Urbano" for the Curitiba location; corresponding search topics in the international database Scopus (As "Article Title, Abstract and Keywords" in the standard search form at http:// www.scopus.com) were "Urban Climate" and "Urban Heat Island" for Curitiba.

\section{Urban climate research in Curitiba}

A great part of the studies on urban climate conducted in Brazil are based on the systematization of the field by the Brazilian geographer Monteiro with his Sistema Clima Urbano (SCU) approach for guiding research on urban climate. ${ }^{8}$ Based on Monteiro's method, urban climate systems can be subdivided into three subsystems: thermodynamic, hydrometeorological, and physiochemical. Each of these subsystems will have an impact on urban environmental quality and should therefore be handled in a systemic way by means of appropriate and climate-responsive urban planning strategies.
The focus of this paper is on the thermal impacts (thermodynamic subsystem) of urbanization in a subtropical location, although one must also recognize the severe consequences for the local economy and quality of life arising from disturbances in the hydrometeorological subsystem, eg, increases in flooding episodes. The thermodynamic subsystem, according to Monteiro, is linked to the perceptual channel "thermal comfort", which includes the determination and mapping of urban heat islands (UHIs). ${ }^{8}$

The survey of studies published on urban climate starting in the 1990s showed that the majority are related to the thermodynamic subsystem/thermal comfort channel. A handful of studies found with the search engine Google Scholar were linked to air quality while a few others were on the hydrometeorological channel. However, the bulk of publications pertain to the thermodynamic subsystem/thermal comfort channel. Such results corroborate the findings from a literature review with the time frame 1990-2010 for the entire country, where most research papers on urban climate were found to have evaluated the thermodynamic subsystem; in particular, for the decade 2001-2010, the thermodynamic subsystem represented over $75 \%$ of the total Brazilian research output in this field. ${ }^{9}$

Although a precise quantification of the total research output for the terms "Clima Urbano" and "Curitiba" as a location indicator is not the aim of this paper, a raw figure for the last 5 consecutive years was approximately 280 hits (results from Google Scholar including citations, papers not directly related to the thermal comfort channel, and those not necessarily taking place in Curitiba); for the 5 years before that, the amount drops to about 230 publications; and since the start of the reported studies in the field in Curitiba until 2005, there were less than 90 hits for primary data.

A filtering of data from the Google Scholar search engine yielded a total of 25 papers, eight master's theses, and seven doctoral theses presented on the subject from 2004 onwards. Preliminary work published as a journal or conference paper before that shows however an effort to quantify inter- and intra-urban temperature variations in Curitiba, though the main focus was not on the UHI effect, but on air quality standards. The exception was the reference book of Monteiro and Mendonça “Clima Urbano", a landmark for studies on the subject in Brazil, which discusses Monteiro's SCU approach and presents an overview of studies on the subject until 2003, the year of its publication.

Danni-Oliveira pioneered the research in the area of urban climate in Curitiba in the 1990s, looking at intra-urban differences in air temperature for the diversified morphology 


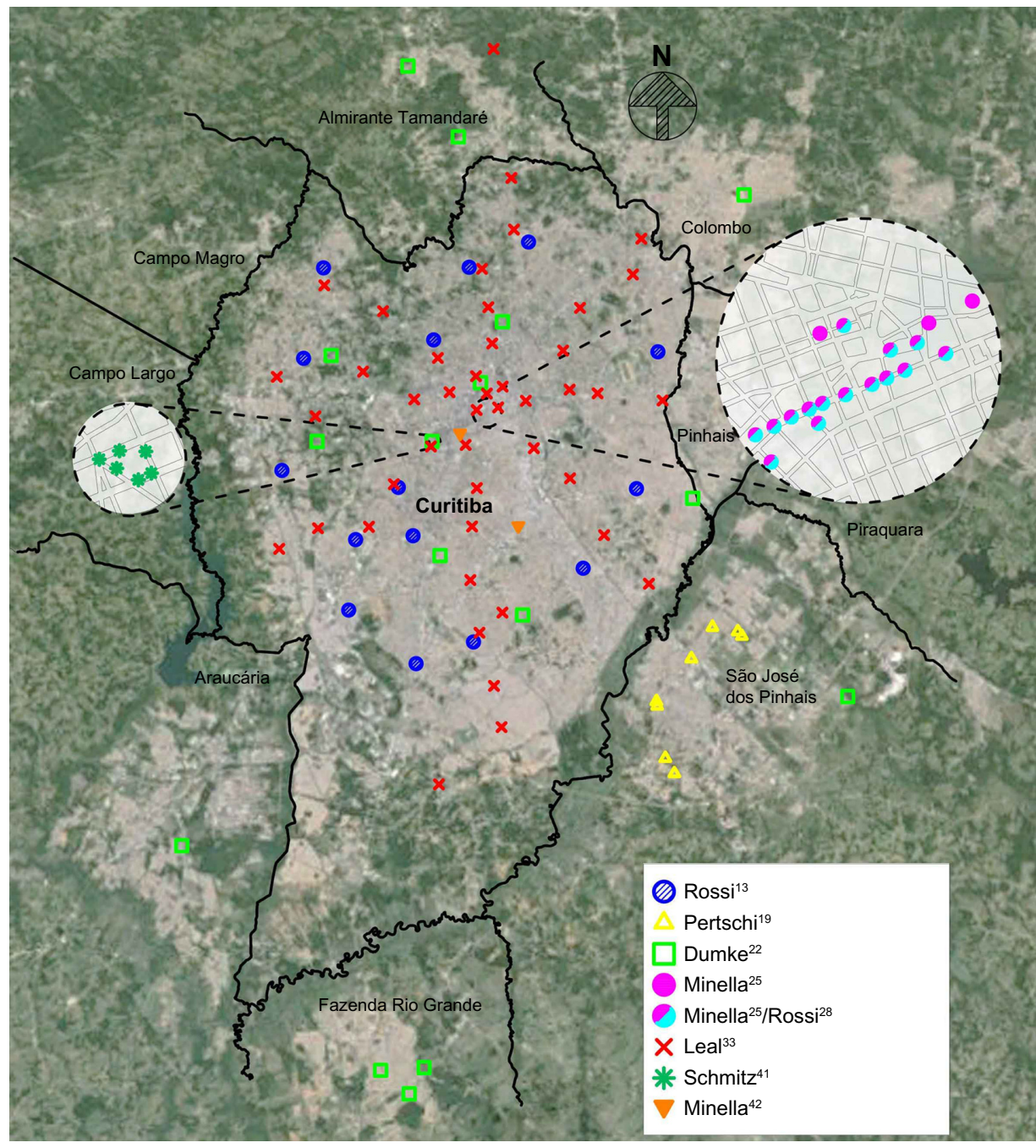

Figure I Spatial distribution of the points covered by fixed monitoring stations over the background of satellite imagery (Google Earth) and street-layout maps from IPPUC. ${ }^{52}$ Notes: Except for the points covered by Pertschi ${ }^{19}$ and Dumke ${ }^{22}$ and a monitoring point studied by Leal, ${ }^{33}$ the bulk of monitoring sites were within the city of Curitiba (PR, Brazil). Minella, ${ }^{25,42}$ Rossi, ${ }^{28}$ and Schmitz ${ }^{41}$ focused on the downtown area, while Rossi, ${ }^{13}$ Dumke, ${ }^{22}$ and Leal ${ }^{33}$ used more widely distributed monitoring sites, allowing for the analysis of heterogeneous situations. Apart from a few points monitored by Dumke ${ }^{22}$ in the Metropolitan Region and by Leal, ${ }^{33}$ the majority of sites were in consolidated urban areas. As for mobile stations, five studies employed such an approach for data collection: Blanchet; ${ }^{17}$ Pertschi ${ }^{19}-$ in addition to fixed point monitoring, as cited above; Barbosa; ${ }^{23}$ Pertschi; ${ }^{27}$ and Martini. ${ }^{35}$

of the city and, in many cases, as a function of traffic levels. ${ }^{2}$ Further analyses of monitoring campaigns showed a relationship between the magnitude of the UHI and atmospheric patterns, such as the occurrence of clear night. ${ }^{10}$

Although the focus of her doctoral thesis was on pollutants' dispersal (Monteiro's physiochemical subsystem), Danni-Oliveira noticed that the massive densification towards vertical growth contributed to a reduction in wind speeds in the canopy layer with thermal implications in urban canyons. ${ }^{2}$ In a subsequent study, Danni-Oliveira et al analyzed the effect of vertical growth, concluding that high-rise buildings were responsible for increases in ambient temperature. ${ }^{11}$ Cunico et al corroborated these findings, suggesting a strong relationship between urban density and increases in air temperature while, in comparison, vegetated areas exhibited lower air temperatures. ${ }^{12}$

More focused studies with the aim of understanding and quantifying intra-urban variations and UHI effects started with field measurements from 2002 onwards, including stationary stations (Figure 1) and mobile transects (Figure 2). Rossi quantified intra-urban air temperature differences by means of simultaneous monitoring with data loggers..$^{13}$ The study started out by updating Curitiba's test reference year, since the test reference year (available for download at http://www.labeee.ufsc.br/downloads/arquivos-climaticos/ formato-try-swera-csv-bin) available at that time was based on a climate database from the 1960s. Results of this update showed a small increase in air temperatures over 


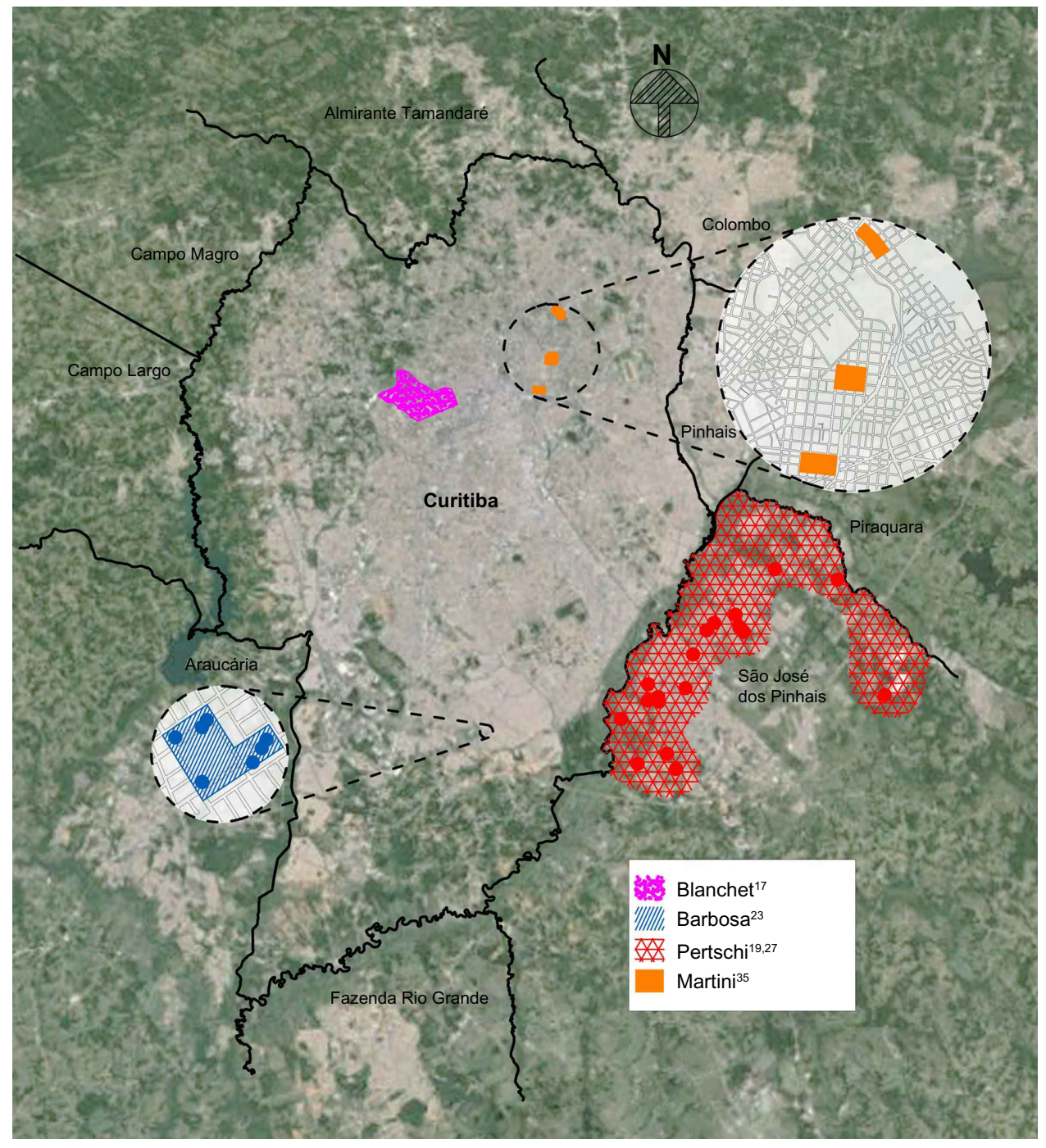

Figure 2 Spatial distribution of the mobile transect measurements over the background of satellite imagery (Google Earth) and street-layout maps from IPPUC.52 Note: Excluding the regions evaluated by Pertschi, other transect measurements took place in consolidated areas in Curitiba (PR, Brazil). ${ }^{19,27}$

the period, with a corresponding reduction of cold thermal stress throughout the seasons of the year. For the field study, measuring instruments were positioned at a common reference height adjacent to public library buildings located in different neighborhoods across the city, and monitoring took place simultaneously at the different locations during winter. By determining land use attributes of the 14 different monitoring sites from aerial photographs - which were classified according to pervious and impervious, vegetated areas, water bodies, and built up areas - correlations were drawn with local air temperatures and their differences relative to those measured at an official meteorological station. Results showed that in some instances, observed patterns conformed to what would be expected from the literature review, but that the correlations between land use and local air temperature were generally weak. ${ }^{14}$
A follow-up study by Lima had the purpose of analyzing the relationship between energy demand for air-conditioning and urban form. ${ }^{15}$ Height and albedo parameters were added to the database gathered during Rossi's study and the analysis was thus expanded..$^{13}$ In addition, computer simulations as well as predictive formulas were used for assessing energy consumption in three low-cost houses for the different sites across the urban area. The simulations were calibrated using actual monitored data gathered in a previous field study. ${ }^{16} \mathrm{The}$ three low-cost houses evaluated in Lima's study presented different building attributes in terms of $\mathrm{U}$-value and thermal mass as follows: 1) a wood-based building; 2) a conventional building with unplastered walls, built with ceramic bricks; and 3) a dwelling built with an alternative building material based on soil-cement blocks. ${ }^{15}$ Special care was given to the overall atmospheric conditions considered for such estima- 
tions from synoptic reports. From predictions of the indoor conditions in the low-cost houses for the various sites, percent changes in heating energy demand due to a virtual relocation of the building ranged considerably. More detailed computer simulations performed for the wood-based building system, which had exhibited the greatest variation in heating demand due to relocation, showed a $40 \%$ change rate in heating alone as a result of urban morphology.

Blanchet used mobile transects, consisting of air temperature and humidity sensors attached to a vehicle, to analyze the relationships between thermal fields and land use attributes in a particular neighborhood (Bairro Bigorrilho, Curitiba, PR, Brazil) at three time stamps (9 am, $3 \mathrm{pm}$, and $9 \mathrm{pm}) .{ }^{17}$ Altogether, 13 monitoring points were monitored in the time frame of 1 hour around the World Meteorological Organization official time stamps, along three transects in summer and in winter, and were compared to a reference station. A thermal comfort index known as the "Building Bioclimatic Chart" was also used for integrating measured variables. ${ }^{18}$ The characterization of each monitoring point according to aspects such as land use, density, and vegetation was based on a combination of in situ observations, official urban planning data, and aerial images, so that a quantification was made possible. Among the conclusions was that vegetation is directly linked to local air temperature changes.

Pertschi investigated the relationship between local urban design attributes and air temperature/UHI effects in São José dos Pinhais, a municipality which is part of the Metropolitan Region of Curitiba. ${ }^{19}$ This study employed fixed monitoring stations and land-use classification (as in Rossi's study), but focused on a summer period in 2005. ${ }^{13}$ Again, Monteiro's SCU approach was used, and the thermodynamic subsystem was evaluated. ${ }^{8}$ The mobile transect method was also employed, with air temperature measurements being sampled across different monitoring sites. Taking into account the background atmospheric changes throughout the monitored period, correlations were drawn between urban design attributes and local air temperature. The weak correlations found were attributed to divergences between aerial images and the sites' roughness-related $3 \mathrm{D}$ features not captured from the overhead view, and also to limitations of the statistical analysis used.

A study by Young at the State University of Campinas in the State of São Paulo (SP, Brazil) also focused on Curitiba, with the aim of studying the relationship between vegetation and thermal changes over time, both expressed as relative indices (vegetation fraction versus local temperature). ${ }^{20}$ The study was carried out by means of remote sensing from
Landsat satellite imagery. Three major areas of Curitiba were grouped according to vegetation profiles, and each area was evaluated at three time stamps (1986, 1999, and 2002) in terms of changes in land use, population patterns, and local thermal patterns. It was possible to verify the importance of the size and distribution of vegetated areas and that changes in landscape design can lead to microclimate changes. Mendonça and Dubreuil, by way of the same method (Landsat satellite imagery) identified a mosaic of heat and cool islands in the urban area as a result of different urbanization patterns, vegetated fraction, and topography. ${ }^{21}$

Dumke investigated the social-spatial inequalities within Curitiba's urban agglomerate and their relation to local climatic features. ${ }^{22}$ The scope of this doctoral thesis goes beyond the physical analysis of measurable variables by also taking into account the vulnerability and quality of life of the lowincome population, which generally lives in the peripheral areas of the city. By means of thermal imagery and in situ monitoring of air temperature and humidity at 16 locations across the urban area, it was concluded that the population living in the outskirts of the urban center suffers from lower temperatures and higher daily swings in winter. Considering that in the southern part of Brazil, low-cost houses are generally not (well) insulated, this finding suggests that such dwellers suffer from thermal discomfort in winter. Common to three studies ${ }^{13,15,16}$ was the emphasis on cold conditions, as Curitiba's winter season presents more challenges to building and city planners than its relatively mild summers.

Barbosa analyzed the direct impact of vegetation on microclimate and indirect impacts on indoor conditions in low-cost dwellings situated adjacent to a green corridor in Curitiba. Mobile transects were employed for the investigation, which compared four pairs of single-family low-cost dwellings (of similar construction and building materials) either with or without adjacent trees and grass surfaces, monitored during late autumn (May to June). ${ }^{23}$ Interestingly, as an attribute of the urban design, the implementation or the preservation of vegetated areas was responsible for a slight reduction of the indoor daily air temperature swing, a factor responsible for indoor thermal comfort. The mobile transects carried out under different clear-sky conditions during five distinct days showed small significant, though not fully consistent, reductions in air temperature and improved comfort conditions due to the presence of vegetation.

With the aim of analyzing the microclimatic effect and consequences to outdoor thermal comfort of another urban design attribute, the sky view factor (SVF), Minella carried out measurements in the main pedestrian street of Curitiba 
(Rua XV de Novembro) with a pair of weather stations, simultaneously positioned in locations with varying SVF. ${ }^{24,25}$ Thirteen daytime monitoring campaigns took place over the months of January through August, 2009. The site's SVF was found to be only moderately correlated with measured air temperature and with the derived comfort index Physiological Equivalent Temperature (PET), though a stronger correlation was found with the mean radiant temperature. ${ }^{26}$

Pertschi also looked at the implications of urban attributes for temperature changes in summer, on the basis of field data from São José dos Pinhais, the most populous municipality in the Metropolitan Region of Curitiba and the site of several industrial plants as well as the city's international airport. ${ }^{27}$ Thermal satellite imagery was used for the definition of ten observation points, which were monitored in the summer of 2011. The study bears similarities in its method to the procedures adopted by Dumke as well as the 2005 study by Pertschi for thermal monitoring in low-cost rain/radiation shields, and by Rossi for the classification of land use attributes and the subdivision of vegetated areas, water bodies, and built-up and impervious areas. ${ }^{13,19,22}$ Furthermore, the study follows Monteiro's 1976 SCU approach. Using a more robust statistical analysis than in Pertschi's 2005 study, the author concluded that the attributes of most monitored points showed a strong relation to local air temperature changes. ${ }^{19}$ An index was then suggested for guiding climate-responsive urban planning, which facilitates the analysis of implications from land use with respect to the resulting thermal effects.

In another line of research, Rossi proposed an outdoor thermal comfort model which could serve as a feasible tool for climate-responsive urban planning. ${ }^{28}$ This doctoral thesis was based on field monitoring campaigns in the pedestrian area of Curitiba, carried out in parallel with Minella's study using a pair of weather stations and questionnaire surveys with passersby during daytime on week days. ${ }^{25}$ Observed thermal sensation votes (from about 2,000 respondents) were compared to calculated thermal stress expressed by the outdoor thermal comfort indices PET and the Universal Thermal Climate Index (UTCI) (http://www.utci.org/). In addition, a thermal sensation predictive model was proposed for Curitiba in two versions: using a linear discriminant function and a logistic regression model. The study suggested a strong need for calibrating the two outdoor thermal comfort indices PET and UTCI, and, indeed, from field data, a calibration of UTCI was subsequently performed in direct collaboration with developers of the UTCI index. ${ }^{29}$

Silva analyzed the influence of green areas on the topoclimate in a winter month accounting for the dynamics of weather types. ${ }^{30}$ The values of the variables were collected at nine monitoring points locally and at three time stamps, and were compared with each other and to data from the official meteorological station Instituto Nacional de Meteorologia. The aim was to evaluate the intensity and spatial extent of the thermal benefits of a 70 ha vegetated area; results showed the importance of accounting for the atmospheric patterns over the monitored periods, which may confound thermal relationships and intensities. A similar analysis has been carried out by Krüger and Rossi ${ }^{31}$ while interpreting data from the small network of dataloggers located across the urban area which showed that relationships may change according to the prevailing atmospheric condition during monitored periods. ${ }^{13}$ Leal et al also came to similar conclusions while comparing results from the extensive database of 44 stations to meteorological variations throughout the monitoring periods. ${ }^{32}$

Leal evaluated the influence of vegetation on microclimate by looking at the temporal and spatial variation of air temperature and relative air humidity monitored at 44 monitoring points across the urban area. ${ }^{33}$ Four stationary transects in the urban area were defined, and monitoring was carried out for 22 days in each season during 2011. The study was able to identify different "microclimatic units" across the urban area, thereby corroborating previous findings regarding intraurban thermal differences in Curitiba. ${ }^{22}$ The categorization of each site was not based on aerial imagery as in the studies by Rossi and Pertschi, but was carried out qualitatively from in situ observations. ${ }^{13,19,27}$ The UHI effect vis-à-vis cool island effect was found in more densified areas and in parks and vegetated areas, respectively. From the network of monitoring points, results from the study corroborated previous findings regarding intra-urban thermal differences in Curitiba. ${ }^{21,22}$ Albeit, the author stated in a follow-up paper that different typologies of urban forests have led to reductions in air temperature across the city, which again stresses the importance of a spatial distribution of vegetated areas; the quantification of such forest typologies by way of an index could bring a more direct application to urban design. ${ }^{34}$

Over the four seasons of 2011-2012, Martini used portable weather stations for heat-stress monitoring together with questionnaire-based outdoor comfort surveys to investigate the daytime effects of vegetation (in streets with and without trees) on local outdoor comfort. ${ }^{35}$ Survey data were later compared to predicted thermal sensation using the UTCI. A categorical change in thermal comfort was observed when moving from an exposed situation to a site with trees. Though the author used the comfort/stress categories suggested by 
the developers of the UTCI, adjustments made to this index for the specific conditions of Curitiba and calibrated from Rossi's 2012 database were not included in the assessment of comfort/discomfort levels. ${ }^{29,36}$

In a later study, Martini et al conducted a mobile transect across a vegetated fraction (Parque Municipal do Barigui) and verified that the horizontal extent of the thermal benefit in terms of cooling of the vegetated area reaches up to $750 \mathrm{~m}$ beyond its borders. ${ }^{37} \mathrm{~A}$ similar study was carried out by some of the coauthors in a substantially smaller urban square with vegetation (Praça Alfredo Andersen) yielding a less effective spatial extent (about $250 \mathrm{~m}$ ) of the cooling effect. ${ }^{38}$ Even though the authors have not quantified the factors responsible for the differing thermal impact over the neighboring area, greenery area and vegetation attributes have been surveyed in such studies, which could allow a future parameterization study with more direct application to planners.

Silva used remote sensing (Landsat satellite imagery) as a tool for understanding the relationship between land use and surface temperatures. ${ }^{39}$ In this study, the Normalized Difference Vegetation Index, which was earlier employed by Young, was used; though in this case, the analysis was extended for the time frame of 1985-2010. As in Young, a rapid deforestation process was noticed which brought an overall increase in thermal stress over time..$^{20}$ Lemos, by means of remote sensing, analyzed the interactions between the built space with climatic characteristics of the Metropolitan Region of Curitiba, investigating the formation of the UHI as well as its spatial relationship with land use and occupation. ${ }^{40}$ From the satellite imagery, three distinct thermal zones were identified which were suggested to be directly related to differing urbanization patterns.

In two independent doctoral theses, Schmitz and Minella used the ENVI-met simulation environment for the analysis of current and future scenarios of urban planning strategies in Curitiba. ${ }^{41-43}$ ENVI-met allows for transient simulations of human biometeorological parameters at selected grid points in urban areas based on meteorological input variables. The two independent studies used field measurements as a means of validating the simulation model for each urban scenario analyzed. From a validated/ calibrated simulation model, alternative scenarios were tested, allowing general guidelines for climate-responsive urban planning to be designed. Both studies used meteorological variables as well as comfort indices as important evaluation parameters, and both also quantified land-use patterns for understanding the relationship between thermal behavior and site attributes.
Whereas Minella proposed a preliminary index relating vegetated fraction and local air temperature variations as a feasible design tool in climate-responsive urban design, Schmitz concluded that mitigation strategies could successfully reduce thermal discomfort in Curitiba in the next 50 years despite global warming trends. ${ }^{41,42}$ It should be stressed that even though Curitiba could in general benefit from the UHI effect (ie, warming trends over time would reduce cold stress in winter), such benefits do not necessarily outweigh the detriments in summer.

Krüger used two independent data sets (microclimate data monitored simultaneously by two weather stations during 2011-2013 and indoor data measured in 18 low-cost houses in winter 2000 and summer 2000/2001) for: 1) estimating indoor temperatures from outdoor temperature data; and 2) subsequently, post-processing-monitored microclimate data as predicted indoor temperature and comfort assessment in low-cost dwellings. ${ }^{44}$ The procedure thus allowed the evaluation of urbanization effects on indoor environments for Curitiba's climatic conditions. Results suggest that the UHI intensity measured in Curitiba over different seasons, despite exhibiting a relatively low mean of about $0.5^{\circ} \mathrm{C}$ over the year, could translate to increased heat stress in low-cost houses located in the urban area. It was verified that increases in indoor temperatures in summer are more significant than a drop in cold stress in winter in the UHI. Similar observations were made by Krüger and Bröde while analyzing the relationship between urban growth and the formation of UHI in Curitiba. ${ }^{45}$ Outdoor thermal comfort conditions were assessed by means of the locally calibrated UTCI, and an estimation of indoor effects of the UHI was carried out for low-cost houses. A projection to more densified conditions was also performed by significantly reducing air speed at night when accounting for urban roughness effects. From both studies, obtained results indicate that the existence of the UHI can be primarily detrimental to indoor thermal comfort in summer, with a smaller effect on improving indoor comfort in winter.

Such findings may contradict conclusions drawn from Dumke's 2007 study, ${ }^{22}$ which stated that the low-income population living in peripheral areas may be burdened by increased cold thermal stress outside the UHI. However, it should be remembered that the thermal aspect is only part of the social vulnerability of the low-income population. ${ }^{46}$ Many central areas of Curitiba offer a proximity to parks and water bodies which positively affect microclimate, though in most cases, such "thermal oases" seem to be restricted to the middle and upper classes. 


\section{Scopus search - international reach}

A search in the Scopus database was performed; at the time of this submission it contained 55 million records of peer-reviewed literature: scientific journals, books, and conference proceedings (http://www.scopus.com). The search for an open time frame using either the term "Urban Climate" or "Urban Heat Island" for the Curitiba location yielded 27 and five hits, respectively. A careful look at the records that were found showed, however, that only seven papers were published in peer-reviewed journals in the international context. Aside from the three groups responsible for the research output on urban climate for Curitiba (there are three major research groups directly or indirectly related to topics on urban climate which are presently active in Curitiba, which are registered in the country's main directory of research groups [http://lattes.cnpq.br/web/dgp] - two of them are based at the Federal University of Paraná and the third is based at the Technological University of Paraná), all papers were written by one research group only (Technological University of Paraná), in some cases in international collaboration. ${ }^{5,14,44,47-50}$

Krüger and Givoni analyzed the influence of land use on intra-urban temperature differences in Curitiba from a small network of temperature/relative humidity weather stations during a 1-month period. ${ }^{14}$ The land-use classifications around each monitored site, obtained by Rossi, ${ }^{13}$ were compared to the minimum, average, and maximum temperatures, registered at each location, qualitatively and quantitatively. As a final step of the study, formulas were developed expressing the local temperatures as a function of air temperatures, solar radiation, and the wind speed of the reference meteorological station.

Kruger summarized the studies by Rossi and Lima discussing land-use effects on local temperatures and consequences in terms of air-conditioning demand (for cooling) in three different building systems. ${ }^{47}$

Krüger et al observed and estimated relations between urban morphology and changes in microclimate and air quality within a city center. ${ }^{5}$ From measured microclimatic data and comfort surveys, carried out in downtown Curitiba, the impact of street geometry on monitored ambient temperatures and on assessed daytime pedestrian comfort levels was evaluated, using SVF as an indicator of the complexity of the urban geometry. The impact of street orientation relative to prevailing winds and the resulting effects of ventilation (air speed and spatial distribution) on the dispersion of trafficgenerated air pollutants were additionally analyzed by means of computer simulations.
Krüger presented a UHI analysis by means of long-term climate monitoring between December 2011 and February 2013 using a pair of weather stations in and outside the urban area of Curitiba ${ }^{44}$ Effects of the local UHI were found in the outdoor space as well as on thermal comfort conditions in low-cost houses. Although it has been suggested that in Curitiba the UHI could prove to be advantageous to offset cold stress in winter, thereby exposing the low-income population in the outskirts of the urban agglomeration to a greater climatic vulnerability (as in Dumke's 2007 study $^{22}$ ), results derived for indoors indicate that the existence of the UHI can be detrimental to indoor thermal comfort under summer conditions, and overall on an annual basis.

In another line of work, Krüger and Rossi showed outcomes from the outdoor comfort campaigns with passersby in downtown Curitiba. ${ }^{48}$ The paper consisted of a data-consistency check, evaluating the relationship between personal (sex and age of respondents) and objective microclimatic (comfort variables) factors on observed thermal sensation.

Two other papers evaluated the applicability of the outdoor comfort index UTCI to the field measurements (outdoor comfort campaigns). ${ }^{49,50}$ Bröde et al analyzed votes of thermal sensation with respect to predictions of UTCI, suggesting that the index is suitable as a planning tool for urban thermal comfort in subtropical regions. ${ }^{49}$ Results showed that the overall pattern of clothing choice was well reflected by UTCI, which also provided for good predictions of thermal sensation votes depending on the meteorological conditions; subgroups analysis indicated that the goodnessof-fit of the UTCI was independent of sex and age, and with only limited influence of season and body composition as assessed by body mass index. In a follow-up paper, in the context of urban planning, it was shown that the UTCI index was able to capture the influence of urban morphology on urban microclimate and its impacts on pedestrian thermal comfort. ${ }^{50}$

\section{Critical evaluation and current perspectives}

From this review, it can be noticed that while several research studies used similar methods and attempted to follow a similar path, in some instances there was a lack of connection with previous work. Examples of such discontinuity can be found in:

- the disregard of the quantitative assessment of land use from aerial imagery in Leal's 2012 study, ${ }^{33}$ which had been pursued by Rossi ${ }^{13}$ and Pertschi ${ }^{19,27}$ in a consistent manner; 


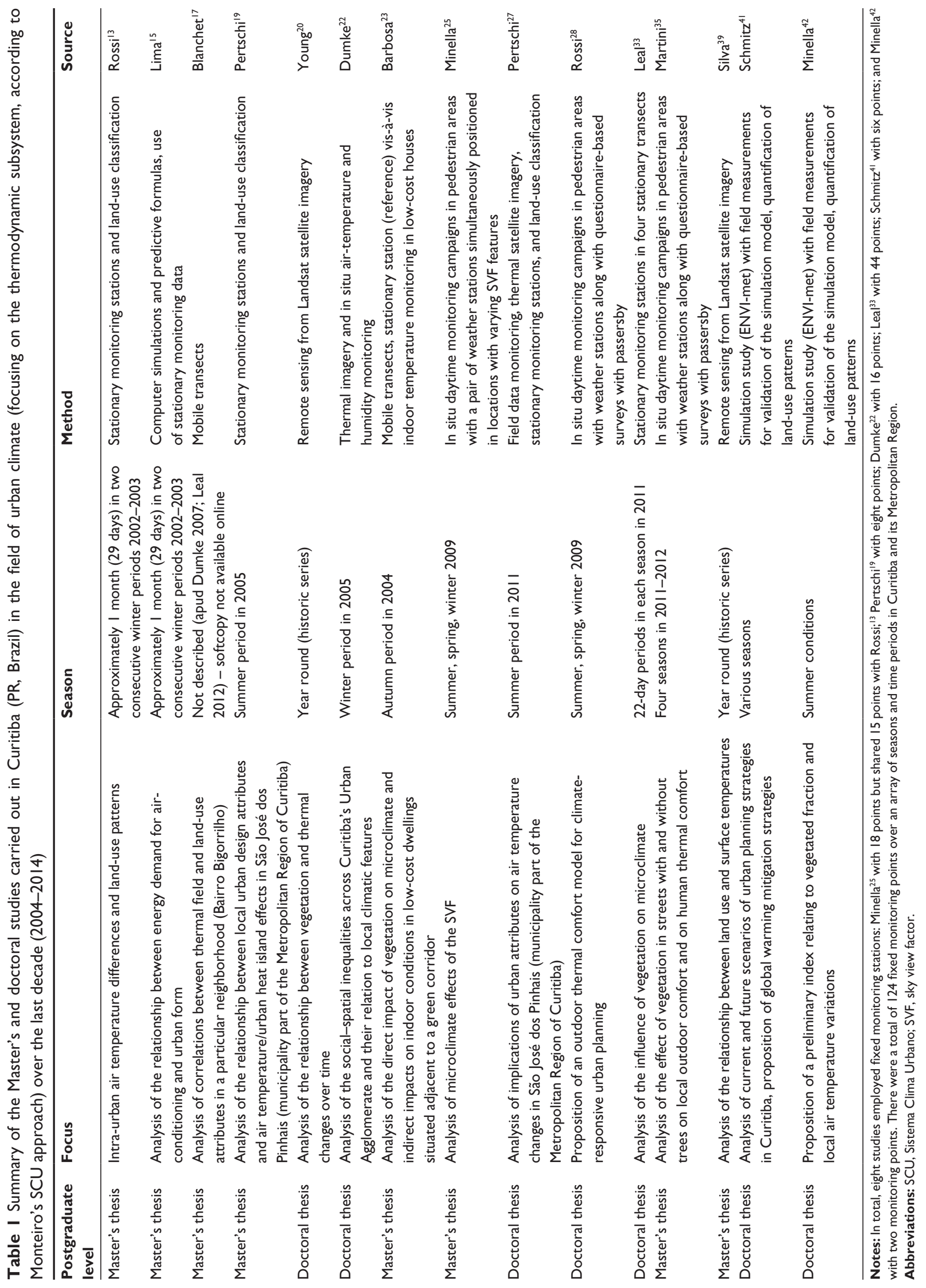


- the use of UTCI classes which were not locally calibrated by Martini, ${ }^{35}$ though a calibration of the index had been previously proposed for Curitiba (Rossi et $\mathrm{al}^{29}$ );

- Martini's ${ }^{35}$ study of the thermal effect of vegetated streets did not mention a similar effort by Barbosa ${ }^{23}$ in which two transects with similar configurations (vegetated versus bare streets) were compared, and did not replicate Rossi's ${ }^{28}$ use of a grey globe thermometer, as recommended for the assessment of outdoor thermal comfort; ${ }^{51}$

- Silva's ${ }^{39}$ study did not mention a previous effort by Young, ${ }^{20}$ which was similar in its methodology and research subject.

From such examples, a duplication of efforts and a discontinuity in research methods become apparent.

Another important point to be stressed here is the strong need for internationalizing urban climate research carried out in Curitiba in peer-reviewed journals and/or open-access journals for a broader audience. The mostly localized (with a national reach, in a few cases) research output could benefit from research collaborations arising from the exposure of methods and outcomes in the international context. In addition, by publishing internationally, methods and findings would be subject to the scrutiny of a broader audience in the respective field, in addition to the peer-review process it undergoes before publication.

\section{Current perspectives}

As presented in this review and summarized in Table 1, urban climate research in Curitiba could be subdivided into three main branches: 1) analysis of intra-urban temperature distribution by means of field measurements or remote sensing; 2) applicability evaluation and/or calibration of existing outdoor thermal comfort indices, and development of novel outdoor comfort indices; and 3) urban microclimate simulation of present and future scenarios.

With regard to the branch 1 , attempts have been made in the studies surveyed to quantify land-use and morphology attributes, but these efforts are still unable to provide meaningful and quantifiable indices for climate-responsive urban design. Even though earlier studies may not be complemented by new indices for the monitored sites due to changes in local urban development over time, the later studies could still come up with relevant indicators of land use and vegetation and successfully be able to generate good predictors of microclimate changes due to land use and vegetation.

The calibration and development of outdoor thermal comfort indices (branch 2) has its importance in the context of Curitiba, as many studies are focused almost exclusively on air temperature and not on thermal indices, which encompass a set of meteorological variables relevant to thermal perception and, consequently, to overall quality of life in the city. Although a robust database has been gathered over the years (eg, by Rossi, with over 2,000 respondents, and Martini, with 175 respondents), research in the field still lacks standardization, which will demand renewed efforts in the future. ${ }^{28,35,51}$

The use of computer simulation (branch 3 ) as well as the development of rules of thumb for climate-responsive urban design are quite important and certainly suggest relevant perspectives for future studies in Curitiba.

Considering the long history of proactive urban planning in Curitiba, the integration of research outcomes obtained so far and the development of the field in a more cohesive way in future studies could allow researchers to provide guidance to urban development and redevelopment schemes for Curitiba, with a benefit to the quality of life of its citizens.

\section{Disclosure}

The authors report no conflicts of interest in this work.

\section{References}

1. Steemers K. Energy and the city: density, buildings and transport. Energy Build. 2003;35(1):3-14.

2. Danni-Oliveira IM. A Cidade de Curitiba ea Poluição do Ar: Implicações de seus atributos urbanos e geoecológicos na dispersão de poluentes em periodo de inverno [The city of Curitiba and air pollution: implications of urban and geoecological attributes in pollutant dispersal in winter] [doctoral thesis]. São Paulo: Universidade de São Paulo USP; 1999. Portuguese.

3. Danni-Oliveira IM. Considerações sobre a poluição do ar em Curitiba-PR face a seus aspectos de urbanização [Considerations on air pollution in Curitiba with regard to urbanization aspects]. RA'EGA-O Espaço Geográfico em Análise. 2000;4:101-110. Portuguese.

4. Krüger E, Suga M. Thermal and daylighting evaluation of the effect of varying aspect ratios in urban canyons in Curitiba, Brazil. Journal of Renewable and Sustainable Energy. 2009;1(3):33108.

5. Krüger E, Minella FO, Rasia F. Impact of urban geometry on outdoor thermal comfort and air quality from field measurements in Curitiba, Brazil. Build Environ. 2011;46(3):621-634.

6. Guimarães PRB. Estudo sobre as relações entre as doenças respiratórias e a poluição atmosférica, variáveis climáticas e áreas verdes, na Cidade de Curitiba, Paraná, Brasil [Study on the relationship between respiratory diseases and atmospheric pollution, climatic variables and green áreas, in the city of Curitiba, Parana, Brazil] [doctoral thesis]. Curitiba: Universidade Tecnológica do Paraná UTFPR; 2013. Portuguese.

7. NBR A. NBR 15220-3: Desempenho térmico de edificações, parte 3: zoneamento bioclimático brasileiro e diretrizes construtivas para habitações unifamiliares de interesse social [Thermal performance of buildings, part 3: Brazilian bioclimatic zoning and construction guidelines for low-income, single-family dwellings]. Rio Janeiro. 2005. Portuguese.

8. Monteiro CA de F. Teoria e clima urbano [Urban climate and theory]. Universidade de S. Paulo: Instituto de Geografia; 1976. Portuguese.

9. Mendonça FA, Lima N, Pinheiro G. Clima Urbano no Brasil: Análise e contribuição da metodologia de Carlos Augusto de Figueiredo Monteiro [Urban climate in Brazil: analysis and contribution of the methodology proposed by Carlos Augusto de Figueiredo Monteiro]. Rev Geonorte. 2012;1:626-638. Portuguese. 
10. Danni-Oliveira IM, Mendonça FA. Contribuição ao estudo do clima urbano de Curitiba, PR: considerações sobre suas características termohigrométricas [Contribution to the study of urban climate in Curitiba, PR: considerations on its thermohygrometrical characteristics]. Conference Proceedings of: IV Simpósio Brasileiro de Climatologia Geográfica SBCG; 2000; Rio de Janeiro. Portuguese.

11. Danni-Oliveira IM, Bakopnyil SMC, Britto DM, et al. Implicações da verticalização no perfil térmico urbano: exemplo de Curitiba-PR [Implications of vertical growth in the urban thermal pattern: the example of Curitiba-PR]. Conference Proceedings of: IV Simpósio Brasileiro de Climatologia Geográfica SBCG; 2000; Rio de Janeiro. Portuguese.

12. Cunico C, Glufke D, Oliveira FAHD, et al. Amostragem dos contrastes termohigrométricos em ambientes distintos de usos do solo do centro de Curitiba, PR [Sampling of thermohygrometrical contrasts in distinct land use environments in Downtown Curitiba, PR]. Conference Proceedings of: V Simpósio Brasileiro de Climatologia Geográfica SBCG; 2002; Curitiba. Portuguese.

13. Rossi F. Análise da influência da ocupação do solo na variação da temperatura em diferentes localidades da cidade de Curitiba [Analysis of the influence of land use on temperature variations in different locations in the city of Curitiba] [master's thesis]. Curitiba: Universidade Tecnológica Federal do Paraná UTFPR; 2004. Portuguese.

14. Krüger E, Givoni B. Outdoor measurements and temperature comparisons of seven monitoring stations: Preliminary studies in Curitiba, Brazil. Build Environ. 2007;42(4):1685-1698.

15. Lima LP. Clima e forma urbana: métodos de avaliação do efeito das condições climáticas locais nos graus de conforto térmico e no consumo de energia elétrica em edificações [Climate and urban form: evaluation methods of the effect of local climatic conditions on thermal comfort levels and energy consumption in buildings] [master's thesis]. Curitiba: Universidade Tecnológica Federal do Paraná UTFPR; 2005. Portuguese.

16. Dumke EMS. Avaliação do desempenho térmico de sistemas construtivos da Vila Tecnológica de Curitiba como subsídio para o estudo de tecnologias apropriadas em habitação de Interesse Social [Evaluation of the thermal performance of buildings systems of the Technological Village of Curitiba as a subsidy for the study of appropriate technologies in social housing] [master's thesis]. Curitiba: Universidade Tecnológica Federal do Paraná UTFPR; 2002.

17. Blanchet IVRP. Análise bioclimática dos parâmetros de conforto térmico humano e sua relação com os índices termo-higrométricos e a forma urbana do bairro do Bigorrilho em Curitiba [Bioclimatic analysis of human thermal comfort parameters in relation to hygrothermal indices and urban form in the Bigorrilho neighborhood in Curitiba] [master's thesis]. Curitiba: Universidade Federal do Paraná UFPR; 2004.

18. Givoni B. Comfort, climate analysis and building design guidelines. Energy Build. 1992;18(1):11-23.

19. Pertschi SC. Padrão urbano de ocupação e temperatura do ar na camada intra-urbana em São José dos Pinhais / PR: situação de verão [Thermal field aspects of the urban area of São José dos Pinhais / PR: summer conditions] [master's thesis]. Curitiba: Universidade Federal do Paraná UFPR; 2005.

20. Young AF. Aplicação de índices relativos de vegetação e temperatura para estudo das mudanças do uso e ocupação do solo: estudo de caso de Curitiba (PR), 1986 a 2002 [Application of vegetation and temperature indices for the study of occupation and land use changes: case study of Curitiba (PR), 1986-2002] [doctoral thesis]. Campinas: Universidade Estadual de Campinas UNICAMP; 2005.

21. Mendonça F, Dubreuil V. Termografia de superfície e temperatura do ar na RMC (Região Metropolitana de Curitiba/PR) [Surface and air temperature thermography in the Metropolitan Region of Curitiba/PR]. RA'EGA-O Espaço Geográfico em Análise. 2005;9:25-35.

22. Dumke EMS. Clima urbano/conforto térmico e condições de vida na cidade: uma perspectiva a partir do aglomerado urbano da Região Metropolitana de Curitiba (AU-RMC) [Urban climate/thermal comfort and living conditions in the city: a perspective from the urban agglomeration of Curitiba] [doctoral thesis]. Curitiba: Universidade Federal do Paraná UFPR; 2007.
23. Barbosa M de A. Influência do paisagismo e tecnologia construtiva no clima e qualidade de espaços residenciais com exemplo na Vila Tecnológica de Curitiba [Influence of landscaping and building technology on the climate and quality of residential spaces from the example of the technological Village of Curitiba] [master's thesis]. Curitiba: Universidade Tecnológica Federal do Paraná UTFPR; 2008.

24. Johnson GT, Watson ID. The determination of view-factors in urban canyons. Journal of Climate and Applied Meteorology. 1984;23(2):329-335.

25. Minella FO. Avaliação da Influência de Aspectos da Geometria Urbana Sobre Niveis de Conforto Térmico em Ruas de Pedestres de Curitiba [Evaluation of the influence of urban geometry aspects on thermal comfort levels in pedestrian streets in Curitiba] [master's thesis]. Curitiba: Universidade Tecnológica Federal do Paraná UTFPR; 2009.

26. Höppe $P$. The physiological equivalent temperature - a universal index for the biometeorological assessment of the thermal environment. Int J Biometeorol. 1999;43(2):71-75.

27. Pertschi SC. Índices de tendências de atributos urbanísticos e a temperatura do ar em São José dos Pinhais/PR, situação de verão (2011) [Trend index of urban attributes and air temperature in São José dos Pinhais/PR, for the summer conditions of 2011] [doctoral thesis]. Curitiba: Universidade Tecnológica Federal do Paraná UTFPR; 2012.

28. Rossi FA. Proposição de metodologia e de modelo preditivo para avaliação da sensação térmica em espaços abertos em Curitiba [Proposition of a methodology and a predictive model for the evaluation of the thermal sensation in open spaces in Curitiba] [doctoral thesis]. Curitiba: Universidade Tecnológica Federal do Paraná UTFPR; 2012.

29. Rossi FA, Krüger EL, Bröde P. Definição de faixas de conforto e desconforto térmico para espaços abertos em Curitiba, PR, com o índice UTCI [Definition of thermal comfort and discomfort ranges for open spaces in Curitiba, PR, with the UCTI index]. Ambiente Construido, Porto Alegre. 2012;12(1):41-59. Portuguese.

30. Silva CA. Análise topoclimática da temperatura e umidade relativa do ar sob influência da Massa de Ar Polar Atlântica (MPA) [Topo-climatic analysis of air temperature and humidity under the influence of the Atlantic Polar Air Mass]. Rev GEONORTE. 2012;2(5):150-161.

31. Krüger E, Rossi FA. Influência das condições sinóticas em monitoramentos térmicos urbanos [Influence of synoptic conditions on urban thermal monitoring]. Conference Proceedings of: VIII Encontro Nacional sobre Conforto no Ambiente Construído ENTAC; 2005; Maceió.

32. Leal L, Biondi D, Batista AC. Condições meteorológicas e diferenças térmicas diárias extremas no clima urbano da cidade de Curitiba [Meteorological conditions and extreme daily thermal differences for the urban climate of the city of Curitiba]. Scientia Plena. 2014;10(1):1-11.

33. Leal L. A influência da vegetação no clima urbano da cidade de Curitiba $-P R$ [The influence of vegetation on urban climate in the city of Curitiba - PR] [doctoral thesis]. Curitiba: Universidade Federal do Paraná UFPR; 2012.

34. Leal L, Biondi D, Batista AC. Efeitos da vegetação na variação térmica da cidade de Curitiba, PR [Vegetation effects on the thermal variation in the city of Curitiba, PR]. Floresta. 2014;44(3):451-464.

35. Martini A. Microclima e conforto térmico proporcionado pelas árvores de rua na cidade de Curitiba-PR [Microclimate and thermal comfort created by street trees in the city of Curitiba, PR] [doctoral thesis]. Curitiba: Universidade Federal do Paraná UFPR; 2013.

36. Martini A, Biondi D, Batista AC, et al. Percepção da população sobre o conforto térmico proporcionado pela arborização de ruas de Curitiba-PR [Population's perception on thermal comfort provided by street trees of Curitiba - PR.]. Floresta. 2014;44(3):515-524.

37. Martini A, Biondi D, Viezzer J, da Silva DA. O efeito microclimático do fragmento florestal existente no Parque Municipal do Barigui na cidade Curitiba-PR [The microclimatic effect of the Barigui Park forest patch in Curitiba-PR]. Ciência e Natura. 2015;37:125-131.

38. Viezzer J, Biondi D, Martini A, da Silva DA. O benefício microclimático proporcionado pela praça Alfredo Andersen na cidade de Curitiba-PR [Microclimate benefits provided by Alfredo Andersen Square in Curitiba-PR]. Ciência e Nat. 2015;37:138-143. 
39. Silva JP. Análise do comportamento térmico da superficie de aglomerado urbano da região metropolitana de Curitiba durante os anos de 1985 a 2010 a partir do satélite LANDSAT-5 [Analysis of the surface thermal behavior of the urban agglomeration of the Metropolitan Region of Curitiba during 1985-2010 from LNADSAT-5 satellite imagery] [master's thesis]. Curitiba: Universidade Federal do Paraná UFPR; 2014.

40. Lemos J. Espacialização da Ilha de Calor do Aglomerado Urbano da Região Metropolitana de Curitiba (AU-RMC) em agosto de 2006 a partir de termografia de superfície [Spatialization of the Urban Agglomeration Heat Island of Curitiba in August 2006 from surface thermography]. Conference Proceedings of: Simpósio Bras Sensoriamento Remoto 15; 2011; Curitiba.

41. Schmitz LK. Reestruturação urbana e conforto térmico em Curitiba/PR: diagnóstico, modelagem e cenários [Urban restructuring and thermal comfort in Curitiba/PR: diagnosis, modeling and scenarios] [doctoral thesis]. Curitiba: Universidade Federal do Paraná UFPR; 2014.

42. Minella FCO. Desenho urbano climaticamente orientado: a influência da vegetação no ambiente térmico externo [Climate-responsive urban design: the influence of vegetation on outdoor thermal environment] [doctoral thesis]. Curitiba: Universidade Tecnológica Federal do Paraná UTFPR; 2015.

43. Bruse M, Fleer H. Simulating surface-plant-air interactions inside urban environments with a three dimensional numerical model. Environ Model Softw. 1998;13(3-4):373-384.

44. Krüger EL. Urban heat island and indoor comfort effects in social housing dwellings. Landsc Urban Plan. 2015;134:147-156.
45. Krüger EL, Bröde P. Impact of Urbanization on Predicted Outdoor and Indoor Thermal Comfort Conditions in a Subtropical Setting. In: Sharma UC, Kumar S, Prasad R, editors. Energy Management. Houston: Studium Press LLC; 2014:1-20.

46. Mendonça F. Riscos, vulnerabilidades e resiliência socioambientais urbanas: inovações na análise geográfica [Urban socio-environmental risks, vulnerability and resilience: chalenges in geographical analysis]. Revista da ANPEGE. 2011;7(1):111-118.

47. Kruger EL. Local air temperature data, predicted energy consumption, and land use patterns. International Journal of Energy for a Clean Environment. 2007;8(2):109-123.

48. Krüger EL, Rossi FA. Effect of personal and microclimatic variables on observed thermal sensation from a field study in southern Brazil. Build Environ. 2011;46(3):690-697.

49. Bröde P, Krüger EL, Rossi FA, Fiala D. Predicting urban outdoor thermal comfort by the Universal Thermal Climate Index UTCI-a case study in Southern Brazil. Int J Biometeorol. 2012;56(3):471-480.

50. Bröde P, Krüger EL, Fiala D. UTCI: validation and the practical application to the assessment of urban outdoor thermal comfort. Geogr Pol. 2013;86(1):11-20.

51. Johansson E, Thorsson S, Emmanuel R, Krüger E. Instruments and methods in outdoor thermal comfort studies - The need for standardization. Urban Climate. 2014;10(2):346-366.

52. Instituto de Pesquisa e Planejamento Urbano de Curitiba - IPPUC. Mapa de arruamento de Curitiba - Edition Aug 2013. Available from: http:// ippuc.org.br/geodownloads/geo.htm. Accessed: June 2015.
Energy and Emission Control Technologies

\section{Publish your work in this journal}

Energy and Emission Control Technologies is an international, peer-reviewed, open access journal publishing original research, reviews, editorials and commentaries on developing technologies to optimize energy production and control of emissions. The manuscript management system is completely online and includes
Dovepress

a very quick and fair peer-review system, which is all easy to use. Visit http://www.dovepress.com/testimonials.php to read real quotes from published authors. 